\title{
Arbitrary power, arbitrary interference and the abuse of power: Corruption, Natural Rights and Human Rights
}

\author{
Hugh Breakey ${ }^{1}$
}

What is the relationship between human rights and corruption? This question can take different forms, including moral, legal, socio-political and economic variants. This paper focuses on two key moral questions, asking whether corruption can violate or impact on people's natural rights (on the one hand) or human rights (on the other). In answer, I aim to establish a strong conceptual link between: (a) corruption's 'abuse of entrusted power'; (b) the 'arbitrary power' targeted by natural rights theorists like John Locke and the broader republican tradition; and, (c) the 'arbitrary interference' with protected freedoms, prohibited by the Universal Declaration of Human Rights. I argue that the deep thematic links between systemic corruption and violations of human rights are stronger than have hitherto been recognized. In the twenty-first century, corruption should be recognized as a 'standard threat' (in Shue's sense) to human flourishing and protected freedoms, vindicating the human right to freedom from systemic corruption.

The paper proceeds as follows. The first two sections deal with preliminary concerns: Section I settles some definitional and conceptual issues, and Section II specifies the paper's focus on moral questions (as distinct from legal, socio-political and economic questions). Section III explores the relationship between natural rights and corruption, arguing that the way Lockean and republican traditions of natural rights prohibited arbitrary power rendered state corruption almost an archetypal rights violation. I borrow the language of Henry Shue to characterize systemic corruption as a 'standard threat' to rights in the twenty-first century. Turning to human rights in Section IV, I focus on the notion of arbitrary interference with protected freedoms employed in the Universal Declaration, and show how well this notion captures the intrusions of systemic corruption. Yet there is a complication that must be considered here: contemporary human rights suffer from an equivocal relationship with one particular entitlement - the right to property. I argue this ambivalence is unfortunate, as property rights are often the very entitlement rapacious rulers want to get their hands on. I suggest that the historical situation at the time of the drafting of the Declaration and its ensuing Covenants may have elided the large-scale threat to human dignity posed by systemic corruption. The final section concludes, reflecting on invocations of 'the human right to freedom from corruption'.

\section{Definitions}

Let's begin with some definitions.

\section{Corruption}

Transparency International's definition of corruption presents a useful starting point: 'the abuse of entrusted power for private gain'. ${ }^{2}$ Various theorists and institutions have attempted to further specify

\footnotetext{
${ }^{1}$ This is the postprint version of: Hugh Breakey, "Arbitrary Power, Arbitrary Interference and the Abuse of Power: Corruption, Natural Rights and Human Rights," Research in Ethical Issues in Organisations 17 (2017), 125-145. The authoritative version of record is available at https://www.emerald.com/insight/content/doi/10.1108/S1529-209620170000017013/full/html

2 See http://www.transparency.org/cpi2011/in detail and http://www.transparency.org/what-iscorruption/
} 
the term's extension, by enumerating the different forms that the abuse of power may take, including usual suspects such as bribery, extortion, embezzlement, influence-peddling, nepotism, and so on ((ICoHRP) \& (TI), 2009, pp. 16-21).

Transparency International's simple definition requires some specification, as ambiguities lurk in both the notion of 'abuse of entrusted power' and the idea of 'private gain'. To specify these notions, we can follow Charles Sampford's (2009, pp. 563-564) observation that corruption is a derivative notion, and that the negative concept of 'abuse' can only be understood in the context of the positive and prior concept of proper 'use', which describes the underlying reason for entrusting power in the first place. An 'abuse of entrusted power' is thus any employment of the power that (typically intentionally) departs from the authorized use, including the prescribed activities, constraints and purposes set down by those who entrusted the power. These aspects of the 'proper use' of the entrusted power will usually be defined in law, and by democratic decision-making. This spotlight on the 'proper use' also helps specify the notion of 'private gain'. Once we have identified the prescribed beneficiaries of the entrusted power, we can identify abuses of power as corruption when they are intentionally performed to benefit through money, resources, freedoms, entitlements, opportunities and favours - anyone outside of the authorized beneficiaries. This set of proscribed beneficiaries includes all those who are the usual heirs of corrupt actions: family members, kinship groups and political parties. In what follows, I will thus speak of corruption as 'the abuse of entrusted power for wrongful gain' (as a shorthand for more definitive: 'the abuse of entrusted power for the gain of unauthorized beneficiaries').

Throughout, because of its focus on entrusted power, this paper explores corruption by or with state authorities, rather than private actors. Even so, the conclusions will carry some application to this latter group. After all, private actors can not only be involved in state corruption as active or passive facilitators, but can even stand at the epicentre of networked corruption systems (Chayes, 2016, pp. 89). As well, purely corporate corruption might itself violate human rights in cases where the corporation effectively holds state-like powers over local citizens.

\section{Systemic Corruption}

The broad notion of corruption can be subdivided in various ways, with a common line of distinction dividing 'grand' corruption (of high level state actors) from 'petty' corruption by low-level officials. For our purposes, an important type of corruption is what I will call systemic corruption. (Commentators use different names to pick out aspects of this phenomenon. Rajagopal (1999, p. 499) highlights 'institutionalized impunity', Sampford (2009, pp. 564-566) speaks of 'corruption systems', while Chayes (2015, p. 136) explores 'malign actor networks'.)

In the limit case of systemically corrupt networks, the entire system of government amounts to a vertically integrated criminal organization: petty bribery and extortion by local public officials facilitate the higher-level 'grand' political corruption that protects and profits from such acts - and vice versa (Chayes, 2015, 2016). Systemic corruption extends beyond just one sector of government; its tendrils intertwine throughout myriad different sources of power, across any public-private divide, giving the network a capacity for resilience, self-protection and expansion. Money, influence, protection, power and resources course through these inter-locking networks in complex ways, giving rise to a toxic environment where attempts at integrity and honesty - rather than at corruption and chicanery - become perilous endeavours. The contagious nature of systemic corruption is hardly a modern phenomenon. Back in the early sixteenth century, Machiavelli (1514/1961, p. 108) could observe that:

A prince who wants to maintain his rule is often forced not to be good, because whenever that class of men on which you believe your continued rule depends is corrupt, whether it 
be the populace, or soldiers, or nobles, you have to satisfy it by adopting the same disposition; and then good deeds are your enemies.

Some human rights violations and impacts can occur through isolated, well-hidden and even opportunistic corruption. However, and as we will see (in Sect. IV), many types of corruption require the support of system-wide networks before they can violate human rights.

\section{Natural Rights and Human Rights}

By 'natural rights', I refer to the entitlements that politico-moral theories of rights set down as each person's intrinsic moral entitlements, owed to them by all other people (whether as citizens in a political system, or as ordinary people in a 'state of nature'). These theories include those like John Locke's, whose works were written in the early Enlightenment, and subsequently influenced later Declarations and Bills of Rights. My aim in exploring natural rights theorizing is to show how some of its large-scale commitments - in particular its concerns with 'arbitrary power' - categorically prohibit corruption. ${ }^{3}$

The content of human rights is set down in the 'International Bill of Human Rights', ${ }^{4}$ including the entitlements enshrined in the Universal Declaration of Human Rights (General-Assembly, 1948), and in the main international treaties on human rights, especially the International Covenant on Civil and Political Rights and the International Covenant on Economic, Social and Cultural Rights (both adopted in 1966 and entered into force in 1976 (General-Assembly, 1966a, 1966b)). While the content of human rights is thus reasonably well-settled, complications do arise when they are treated (as I am treating them here), as moral entitlements, rather than purely legal entitlements corresponding to specific state responsibilities. ${ }^{5}$ My intention is merely to set out plausible ways whereby - if we take human rights as setting down universal entitlements owed morally to every person on the basis of respect for their humanity - corruption will breach those entitlements.

\section{Moral, legal, socio-political and economic questions}

Several different questions lurk within the broad question, 'Is corruption linked to human rights violations?' We can isolate moral, legal, socio-political and economic questions.

A moral or normative perspective will ask: "Does corruption violate or impact upon people's natural rights?" and, "Does corruption violate or impact upon the human rights laid down in the Universal Declaration of Human Rights?"

Legal analyses will take a different perspective, querying: "Does corruption constitute state failure to fulfil its human rights obligations under constitutional, domestic or international law?" ((ICoHRP) \& (TI), 2009; (OHCHR), 2013; Boersma, 2012; Rose, 2016). If corruption does violate state

\footnotetext{
${ }^{3}$ That said, the natural rights tradition constitutes a long and diverse philosophical movement. All natural rights theories will agree that (at least certain types of) corruption violate natural rights (based on reasons set out at the beginning of Sect. III). But my most important conclusions apply foremost to the specifically Lockean and republican parts of that tradition that prohibit arbitrary power - a prohibition that (as we will see) renders corruption an almost archetypal violation of natural rights.

${ }^{4}$ While this is a common way of describing the content of human rights, it does skate over subtle questions about, for example, the entitlements found in instruments outside these core multilateral treaties, or in refugee or international humanitarian law. While significant in some respects, such complexities should not impact significantly on the Sect. IV's conclusions.

${ }^{5}$ For some of the issues involved in theorizing human rights as moral entitlements, see, e.g., (Breakey, 2015; Griffin, 2008; Sen, 2004; Shue, 1980).
} 
responsibilities, then this opens further legal questions, such as whether remedies can be sought through the jurisdiction of relevant domestic, constitutional, regional or international courts (Hatchard, 2010).

An economic approach differs again, enquiring whether corruption stymies (or, alternatively, facilitates) sustainable development and economic activity - and whether it does so in such a way as to ultimately impair (or improve) citizens' economic and social rights.

Finally, theorists may ask socio-political questions about corruption's cultural and institutional dimensions, such as whether corruption is hindered by established human rights practices, including increased media freedoms, the institutional protection of the 'right to information', the legal protection of dissidents' free-speech, and political tolerance of community activism (Kumar, 2011).

These various types of questions must be approached distinctly, as none of the above queries simply collapse into the other. For example, some types of corruption might turn out to stimulate economic development even as they impact deleteriously on civil and political human rights.

In particular, the moral questions differ from the legal ones. Legal questions can hinge on issues of justiciability and jurisdiction, which pertain to the possibility of a court being able to render a definitive judgment on a discrete case. Legal analyses will also confine themselves to state duties, rather than the obligations of individual people (as states are enrolled as duty-bearers through constitutional law, or as signatories to multilateral conventions). Moral systems suffer from no such limitations. They may impose duties on anyone, whether ordinary citizens or state officials. As a result, the moral and legal links between corruption and human rights must be considered separately. It may be that - as a moral matter - a state official's action intentionally violates a citizen's human rights, even if - as a strictly legal matter - the state as a whole has not breached its legal responsibilities.

While prior literature has explored the legal questions in some depth, ${ }^{6}$ this paper investigates the two moral questions noted above, beginning with the links between corruption and violations of natural rights.

\section{Corruption and Natural Rights}

Most moral-political philosophies will hold that corrupt acts count as (at least) a prima facie moral or political (and not just legal) wrong. Simply, if corruption is the abuse of entrusted power, then in terms of political philosophy, whatever justified the power being entrusted hinged on the bearer using that power within the bounds and for the purposes for which it was entrusted. Equally, in terms of moral philosophy, corruption inevitably implies a kind of deceit and abuse of trust - both straightforward failures of common-sense moral duties.

For this reason, corruption has proved an age-old concern of political theorists and commentators of myriad stripes, across centuries and cultures. Chayes (2015, pp. 8-19) recounts the Mirrors for Princes, written for Christian and Islamic royalty, that continually stressed the importance of keeping one's hands - and the hands of one's ministers and officials - off the property of one's subjects. Indeed, even Machiavelli, writing in the most (in)famous of the Mirrors (and hardly a thinker given to unnecessary moralizing) cautioned against rising taxes and stressed that: "the prince can always avoid hatred if he abstains from the property of his subjects and citizens and from their women." (1514/1961, pp. 36, 123, 197, 102).

\footnotetext{
${ }^{6}$ See, e.g., ((ICoHRP) \& (TI), 2009; (OHCHR), 2013; Boersma, 2012; Hatchard, 2010; Rose, 2016).
} 
This section explores the way that natural rights theories - a subcategory of moral theories more generally - would view corruption.

\section{John Locke, republicanism and 'arbitrary power'}

John Locke's (1690/1947) Second Treatise of Government developed his influential account of natural rights and political legitimacy. His theory portrayed the use of one person's arbitrary power over another as the hallmark of injustice and a clear breach of natural law and human equality. ${ }^{7}$ For Locke, 'arbitrary power' involved being subject to another's 'arbitrary will', by which he refers to decisions made at pleasure - unbound by the purposes of entrusted power and the limits of natural law. He viewed decisions of an arbitrary will as sudden, inconstant, uncertain and unknown, and often illegal and against the moral law. Such decisions, he argued, were usually exorbitant, unlimited and bedevilled with temptation. ${ }^{8}$

On Locke's view, being subject to arbitrary power meant that another person could make arbitrary decisions that interfered with or harmed one's life and person, as well as (the signature targets of corruption) one's fortunes, property and estates. To be subject to someone's arbitrary will in this way amounted to being made subordinate, in much the same way that a slave is held under another's dominion.

Lockean natural rights called for laws that prohibited any person from imposing their arbitrary will on any other person - whether through mechanisms of dependency, threat or coercion. These mechanisms are all dangers in Locke's state of nature, and Locke sees the shift to political society occurring when a community entrusts the power to use coercive and punitive force to a system of government (Nacol, 2011). The main reason such trust is a dangerous (if necessary) expedient is because the political authority can abuse the trust, and itself wield an even more devastating arbitrary power over the citizens that created it. It was on this point that Locke (1690/1947, §II:93) famously rebuked Hobbes, arguing that the latter's social contract required supposing that, "men are so foolish, that they take care to avoid what mischiefs may be done them by pole-cats, or foxes; but are content, nay, think it safety, to be devoured by lions." Rejecting Hobbes' authoritarian vision, Locke (1690/1947, §§II:132-159) developed an account of democracy and the separation of powers, that aimed to diminish the potential of state power being used to rule arbitrarily.

Lena Halldenius (2003, p. 576) links this fundamental repudiation of arbitrary power lying at the core of Locke's thought with the type of freedom prized by recent thinkers like Philip Pettit. In Freedom as Antipower, Pettit (1996, p. 576) valorised the longstanding republican vision that citizens should be free in the sense of "not being subject to the arbitrary power of another". Noting Locke's membership in this tradition, Pettit $(1996$, pp. 578, 581) explained this specific sense of freedom as the absence of

\footnotetext{
${ }^{7}$ Locke does not provide a specific definition of 'arbitrary power'. The following characteristics of the concept, and its implications in Locke's thinking, are drawn from his (1690/1947) Second Treatise: $\S \S I I: 22-24,135-7,156,163-66,172,221-24$. See also: (Halldenius, 2003, p. 263; Tully, 1980, p. 286).

${ }^{8}$ The term's current dictionary meaning relates these same features of being, "not planned or chosen for a particular reason: not based on reason or evidence" and "done without concern for what is fair or right": http://www.merriam-webster.com/dictionary/arbitrary. These meanings follow the term's earlier meaning, which acquired the specific notions of 'capricious' and 'despotic' around the time of Locke's writing. See http://www.etymonline.com/index.php?term=arbitrary
} 
others' powers to, with impunity and at will, "interfere in the affairs of the other and to inflict a certain damage." $"$

Pettit's (1996) work, and the republic tradition more generally, helps bring into focus the manifold evils of being subject to political authorities wielding arbitrary power. In particular, this tradition highlights that, "the existence of a certain kind of power relation, regardless of how it's put to use, is sufficient for domination..." (McCammon, 2015, p. 1032). In other words, the impact of political domination through arbitrary interference stretches beyond the precise sum of the goods - in terms of liberty, entitlements to services, and property - that are actually wrenched from citizens. Instead, the ongoing condition and prospect of being subject to arbitrary power infects the standing relationship between subjects and political elites. The subjects are always dominated, in the sense that they are continually held in a situation where arbitrary interference may strike and tear them from their most fundamental projects and commitments. The standing relationship of domination thus stirs a hornet's nest of evils, including:

Social impact: Arbitrary power undermines the social status of the dominated subjects, who cannot look others in the eye as their equals, and stand up to them if necessary;

Democratic impact: Arbitrary power strips the capacity of subjects to take part in collective decision-making, for they cannot afford to announce or support opinions contrary to those of their dominators;

Autonomy impact: Arbitrary power undermines the subject's capacity to plan and direct their own lives, as they cannot be sure when the dominator's arbitrary will and power will strike;

Integrity impact: Over time, the arbitrary authority impacts on the subject's very character, encouraging servility, fear, hypocrisy and obsequiousness - traits that strip a person of the capacity for integrity (Breakey, 2016, pp. 614-616);

Morality impact: Arbitrary power interferes with subjects' moral capacities, as their efforts to be fair and just can be stymied at will by their dominators, making playing by the rules impossible. Over time, such interference can impact on their moral character. As a result, systemically corrupt regimes systemically corrupt their citizens (see (Chayes, 2015, p. 132)).

The republican tradition, as exemplified in natural rights figures like Locke, thus helps us conceive of the full gamut of moral concerns triggered by relations of arbitrary power.

Locke's stance on arbitrary power is also illustrated in the way that he pictured people's natural rights and entitlements as their 'property' (Locke, 1690/1947, §§II:27, 34, 44, 135-140, 194). Property ownership allows personal and even arbitrary choices by the owner over their property. Equally however, it categorically prohibits others exercising arbitrary power over the owner's property, at least in any way that interferes with their use of it. By granting people property in not only their fortunes and estates, but in their bodies, rights and labours, Locke's polis is thus one where each person, qua selfowner, stands protected from subjection to others' arbitrary wills (Breakey, 2011).

The links to corruption in all this should be clear. ${ }^{10}$ The abuse of entrusted power for personal gain is precisely what Locke's polis strives to avoid; the type of small-scale enslavement such abuse allows

\footnotetext{
${ }^{9}$ Recent philosophical work on domination has further refined the concept of arbitrary power, see (Lovett, 2012; McCammon, 2015)

${ }^{10}$ Locke (1690/1947) himself was alive to the threat of state corruption (Second Treatise: $\$ 222$ and, in the context of public administration, see (Tuckness, 2008, pp. 265-267). Of course, in Locke's day, state thievery occurring through authoritarian tyranny had less need to cloak its avarice in the garb of
} 
constitutes for Locke the very quintessence of injustice. Corruption by those with political power - at least whenever the corruption significantly impacts on a person or collective - almost by definition constitutes a person using their political authority to subject another to their arbitrary will. As we have seen, that political authority is, for Locke, necessarily an entrusted (and not a natural) power (Nacol, 2011). Corrupt actors intentionally use the entrusted power to cater for their arbitrary pleasures. While other theorists (like Kant - see Breakey (2011, p. 191)) also prohibited arbitrary power, Locke's use of the term 'property' to refer to a person's natural rights foregrounds issues of state theft as an archetypal rights violation, making the link to state corruption pellucid.

The evils of the relationship of domination, characterized by the capacity for arbitrary power, (as noted above by modern republican thinkers) help vindicate why systemic corruption is such a driving concern of those populations forced to labour under its yoke. When considering arbitrary power's manifold social, democratic, autonomy, integrity and morality impacts, we can begin to glean why domination itself can be the fundamental problem, rather than the actual interference that might (or might not) occur in any given instance. For this reason, we can expect those subject to arbitrary power to chafe against the political condition itself, as much as the specific harms such domination inflicts.

Summing up, natural rights thinking - and the Lockean and republican tradition more specifically repudiates any person dominating another through the exercise of arbitrary power. As an abuse of entrusted power for wrongful gain, corruption stands - alongside tyranny, threats and physical coercion - as a paradigm example of a natural rights' violation.

\section{Moral rights and 'standard threats'}

'Moral rights' can be understood as the contemporary (and secular) version of natural rights, laying down fundamental interests and freedoms that must be protected for the sake of human wellbeing and dignity. Recent scholarship on this topic provides a helpful vocabulary for thinking about the natural (or moral) right to freedom from corruption. Henry Shue (1980, p. 13) argues that: "A moral right provides (1) the rational basis for a justified demand (2) that the actual enjoyment of a substance be (3) socially guaranteed against standard threats." The 'substance' in question can be understood as a key human interest, need, freedom or capability that warrants political protection and promotion. ${ }^{11}$ In turn, a 'standard threat' is a factor that is known to prevent or hinder the enjoyment of the right 'to a major degree' (Shue, 1980, p. 32). Fulfilling a right thus requires putting in place effective (though not necessarily infallible) social arrangements to guard against such threats. ${ }^{12}$ At different times and in different societies, the earmarked interests may be threatened by different factors. When social arrangements can be feasibly changed to effectively mitigate against these threats, then fulfilling the person's right requires everyone working to develop and preserve those protective social arrangements. Sometimes multiple solutions will be required to deal with the same threat, or with a set of multiple threats. Jeremy Waldron (1993, pp. 212-222) explains this by speaking of 'waves' of duties that correspond to a single right: if one set of social arrangements fails to secure the protection of the interest, then other backup social arrangements can be made.

democracy, rights and the rule of law (a subterfuge employed by many contemporary malign actor networks (Chayes, 2015)).

${ }^{11}$ See (Raz, 1986; Sen, 1970; Waldron, 2005). I shall henceforth refer to the protected quality as an 'interest', but I employ this term purely for expository ease. I do not wish to prejudice whether the core of a given natural right is best conceived as an interest, freedom, need, or capability.

${ }^{12}$ See similarly Buchanan (2010, p. 54) who links moral rights with human rights, and highlights the importance of institutions in dealing with such threats. 
This vocabulary allows us to better capture the meaning of calls for a 'right to freedom from corruption'. Such an assertion is not putting forward a 'new' right in the sense of locating a new interest that deserves protection. Rather, the call draws attention to a particular 'standard threat' that jeopardizes interests that are already earmarked for rights-based protection. People's interests in property, education and speech, and to freedom of religion and association, are already well-established. The right to freedom from corruption simply captures the way that these pre-existing rights can be imperilled by the standard threat of widespread corruption. Speaking of the right to freedom from corruption thus allows reformers to consider the waves of duties that can be fruitfully deployed against this new standard threat to their rights.

But is the threat a 'new' one, or just a newly uncovered one? I return to this question in the closing of the next section, where I speculate on why, during the period when human rights were being developed, systemic state corruption was not recognized as a standard threat to human freedom and dignity.

\section{Corruption and the Universal Declaration of Human Rights}

This section begins by outlining the different ways corruption can impact on human rights, before turning to thematic issues of arbitrary interference and the right to property.

\section{Different types of violations triggered by corruption}

Corruption can trigger human rights violations in several different ways, both individually and collectively, and intrinsically and instrumentally. ${ }^{13}$

\section{Intrinsic individual violations}

Certain discrete acts of corruption can constitute by their very nature a direct violation of a specific individual's human rights. Examples of such intrinsic individual violations (referenced to the Articles of the Universal Declaration (General-Assembly, 1948)) include:

- The corruption of criminal justice institutions, such as through judicial bribery or partiality, or the use of arbitrary detention as a lever to extort payment. These corrupt practices violate the human rights to a fair trial and due process (Art.10, 11), to equality before the law (Art.7), to liberty and security (Art. 3) and against arbitrary detention (Art.9).

- Extortion in the provision of rights-based state services to specific individuals constitutes an extra-legal with that individual's human rights. The specific right violated depends on the service held hostage, for example with respect to human rights to housing, food and healthcare (Art.25), to freedom of movement (Art.13), to security (Art.3), to privacy (Art.21), and so on.

Intrinsic collective violations

Other acts of corruption may only constitute human rights violations when they become networked and systemic. Rather than discretely violating specific individual's rights, such violations may assault the citizenry's human rights en masse. For example:

- When systemic corruption spreads through the entire system of government, effectively transforming it into a horizontally and vertically integrated criminal regime, this sunders the link between citizenry and democratic decision-making, enshrined in their human rights to take

\footnotetext{
${ }^{13}$ Rajagopal (1999, p. 500) distinguishes 'thematic' (intrinsic) versus 'structural' (instrumental). The examples provided in this section do not exhaust the ways that (especially systemic) corruption can intrinsically violate and instrumentally impact on human rights. For further examples, see ((ICoHRP) \& (TI), 2009; Boersma, 2012; Rajagopal, 1999) as well as the reports of major human rights agencies: e.g., ((HRW), 2015).
} 
part in, and to have their will expressed through elections in, their country's government (Art.22).

\section{Direct instrumental impacts}

Some acts of corruption, even if large in scale, might not constitute a direct violation of citizens' human rights, but may, nevertheless, impact deleteriously on those rights. This impact can happen in a quite direct manner, for example:

- Widespread embezzlement and capturing of revenue streams can strangle the resources of other government institutions necessary for human rights. For example, Human Rights Watch ((HRW), 2015, pp. 178-179) reported that corruption undermines the fulfilment of key social and economic rights such as basic healthcare (Art.25) and education (Art.26) in Côte d'Ivoire. On a like theme, Chayes (2016, p. 17) observed the hollowing out of the military budgets in Nigeria and Iraq that left the population vulnerable to the predations of insurgents, and so of the violation of their most fundamental rights of life, liberty and security (Art.3).

- Corrupt state officials can profit by playing a role in criminal practices like human trafficking, which can themselves directly violate human rights - for example through forced prostitution and forced labour (slavery). Often such criminality will be effectively an extension of the corruption network (Chayes, 2016, p. 23). However, in cases where the relationship between the corrupt and criminal groups is more arm's-length, corruption will work instrumentally as a facilitator of human rights abuses committed by other groups.

\section{Indirect instrumental impacts}

In other cases, the causal link between the acts of corruption and the ultimate impact on human rights may be less direct:

- Exposure of rampant systemic corruption routinely fuels citizen outrage at the national government. This can impel governments to resort to the use of force and intimidation (violating Art's.3, 9, 10, 19) to silence journalists and activists ((HRW), 2015, pp. 82, 84, 129, 156). The civilian outrage can eventually ignite civil strife, violent crackdowns and even extremist insurgencies (Chayes, 2015, p. 183).

The foregoing summarizes the main ways that acts of corruption impacts on specific human rights. However, there is a deeper conceptual connection between corruption and human rights violations, which lies in the notion of 'arbitrary interference'.

\section{Arbitrary interference}

In the Universal Declaration of Human Rights, 'arbitrary' interference with protected freedoms is prohibited in four articles (Articles 9, 12, 15, 17), covering concerns with arrest, detention, exile and nationality, and protecting freedoms including privacy, family, home, correspondence, honour, reputation and property. In each case, the Declaration's use of the term 'arbitrary' connotes more than merely 'illegal' (Hassan, 1969). As we would expect from the above discussion of 'arbitrary power', the Declaration uses the word 'arbitrary' to connote injustice, unreasonableness and immorality. It conveys a clash with the rule of law or with the Declaration's principles and spirit, a failure to accord with common morality or social flourishing, or a decision about the use of state power that fails to be governed by explicit and objective reasons (reasons that justified the power in question). Recent human rights jurisprudence has followed this lead, understanding arbitrariness as being inappropriate, unjust, lacking predictability, unreasonable, or unnecessary and disproportionate (Shah, 2014, pp. 263-264).

The Declaration's over-arching Article 29 conveys a similar idea. It states: 
In the exercise of his rights and freedoms, everyone shall be subject only to such limitations as are determined by law solely for the purpose of securing due recognition and respect for the rights and freedoms of others and of meeting the just requirements of morality, public order and the general welfare in a democratic society.

Article 29 thus requires that whenever states limit the Declaration's protected freedoms, such limitations must meet a double-condition: the restrictions must occur in law, and only for the specific purposes set down in the Article. Since arbitrary interference breaches both these conditions, Article 29's requirement prohibits arbitrary interference with any of the Declaration's protected freedoms.

We have seen that corruption is by definition performed for wrongful gain, and so not for the "just requirements of morality, public order and the general welfare". It therefore follows that whenever corruption impacts negatively on protected interests and freedoms, it constitutes an arbitrary interference and a violation of Article 29. In such cases, the specific human right being violated will depend upon what freedom the corrupt actor wields arbitrary control over: education, health, movement, freedom from arrest and detention, or even property itself ((ICoHRP) \& (TI), 2009, pp. 31-61).

This means that even in cases where corruption is not accompanied by paradigm state human rights abuses (such as torture and arbitrary detention), the corruption itself constitutes a human rights violation whenever it interferes with any of the protected interests or freedoms. Of course, the violation's seriousness in such cases will hinge on how substantially it impacts upon the protected freedom, as well how deeply the corruption impacts across a person's life and actions.

Indeed, a human rights perspective can help us direct attention to the most morally invidious forms of corruption, and of arbitrary interference more generally. In his discussion of arbitrary power as domination, Pettit (1996, p. 581) observes that, "domination in some areas is likely to be considered more damaging than it is in others..." Human rights instruments help inform this judgment by setting down the interests most central to human wellbeing and dignity. When corruption degrades these interests, it becomes a matter of signal moral importance - arguably even meriting international concern (Beitz, 2009).

In sum, in a manner clearly reminiscent of the above discussion of natural rights, contemporary human rights prohibit arbitrary interference with the protected interests. Since the abuse of entrusted power for wrongful gain necessarily amounts to arbitrary interference, any time state actors' corrupt acts work to delay, extort, distort or otherwise interfere with a protected freedom, they fail in their moral duty to respect human rights.

\section{The human right to property}

Perhaps the most straightforward violation of human rights occurs with respect to the right to property. Acquiring property is, after all, an all-too-typical goal of most corrupt actors, especially when it comes to systemic corruption, which is often synonymous with kleptocracy, and typified by enrichment strategies and the capture of revenue streams (Chayes, 2015, 2016). Even if property and wealth are not desired purely for their own sake, they serve as an all-purpose means to pursue other goals, such as the protection and extension of political power.

Like the above-noted human rights, corruption can impact on property rights in different ways (for concrete instances of the following examples, see Chayes 2015, 2016).

Some takings will be intrinsic individual violations. These breaches can include:

- Expropriation of privately owned land through corrupt eminent domain, forged documents or land redistribution 'reforms'. 
- Seizure of goods through official or unofficial means, such as the controllers of a dock abusing their customs-enforcement powers by confiscating containers of merchandise.

- The setting of deliberately prohibitive rates or business taxes, to force business-people and workers to bribe officials to keep their businesses or sources of employment viable.

Other types of takings will violate rights en masse - but only when the corruption reaches a systemic threshold. Cases of intrinsic collective violations of property rights may include:

- Systemic embezzlement of tax funds, rendering tax collecting an arbitrary and illegal taking rather than a legitimate rights-based, and democratically-authorized, constraint on propertyholdings.

- Theft (through diversion into private hands) of the state's natural resources and assets, which should be held as common property, or at least operated in trust for the citizenry at large (see Art.22).

All that said, human rights law equivocates on the significance of the right to private property (Jacobs, 2013). For our purposes here, the problem is not the allegedly weak protections offered by human rights of property against state expropriation and taxation - a common lament of libertarians (Mchangama, 2011). Even the most minimal protection against arbitrary interference (such as in the Declaration's "No one shall be arbitrarily deprived of his property") will suffice to prohibit self-serving state actors' direct depredations on citizen's property. Instead, the problem is that while private property enjoys this basic protection in many state constitutions, some regional human rights instruments (especially in the European Convention on Human Rights ${ }^{14}$ ), and in the Declaration, global human rights covenants fail to protect the right to property. The human right to property set down in the Declaration's Art. 17 failed to be replicated in either the International Covenant on Social and Political Rights, which included most of the other traditional civil and political rights, or the International Covenant on Social, Economic and Cultural Rights, which covered other economic rights.

From the perspective of concerns with corruption and the exercise of arbitrary power, this creates an unfortunate gap in the global human rights regime. While state corruption can use all sorts of other human rights (liberty, education, health and so on) as a lever to deprive victims of their property (money, land, resources, profits, crops), it is often the property itself that the corrupt regime, and its cronies, is after. It thus turns out that the one personal entitlement that is most vulnerable to systematic extortion by criminally corrupt regimes is the very entitlement most weakly protected by international human rights instruments. So much so, that when the International Council on Human Rights Policy (2009, pp. 31-60) catalogued the myriad of human rights capable of legal violation by various types of corrupt acts, the right to property - the very entitlement that rapacious criminal organizations masquerading as states want to get their hands on - was left unmentioned.

Human rights protections are crucial because regimes in power can often benefit by suppressing various citizen's rights, especially those rights that protect political criticism, activism and representation. But individual officials in power can always benefit from expropriating a civilian's property. Uniquely among rights, property is alienable and transferable. If Ruler Amy violates Subject Bob's freedom of movement or association, she doesn't thereby get those freedoms for herself. But if Amy corruptly

${ }^{14}$ ECHR, Protocol No.1 (Art.1). This article effectively echoes the UDHR protections. While not offering any barrier to the imposition of legitimate taxation, it protects possessions from deprivation, except in the public interest and subject to the conditions provided for by law and by the general principles of international law. 
violates Bob's rights of property, then she might well be able to transfer Bob's rights directly into her own repertoire of entitlements. For this reason, private and personal property need the same level of protection from arbitrary interference enjoyed by other rights.

This opens the question of why private property rights went unprotected in the major Covenants, given their presence in the Declaration (and given the previous discussion about arbitrary power). History suggests that states negotiating the Covenants agreed in principle to the idea of protecting property, but were confronted with contestation on many of the particulars raised by such a right (Jacobs, 2013). There are, for example, many different forms of property rights, including common property, community-property, resource property rights (hunting, fishing, riparian, mining, tree-felling etc.), personal property and private property (Breakey, 2012). Property rights also need to be subject to many types of regulation (not least environmental and zoning regulation) and state expropriation through taxation and eminent domain.

With a little political will, these challenging obstacles could perhaps have been worked through. Even enshrined as natural or human rights, property rights can be still be legitimately constrained by regulation and taxation, through employing the same devices by which all other rights have limitations imposed on their strength and scope (Breakey, 2014b). Indeed, John Locke - perhaps the most influential defender of property in western philosophy - allowed for quite nuanced property rights, including liabilities to regulation and taxation (Breakey, 2014b, pp. 591-598).) Arguably though, the political will for overcoming such obstacles may not have been present because - at that particular juncture in time - networked state thievery was not seen as a standard threat to human dignity. Let us briefly turn to this possibility before concluding.

\section{Why wasn't corruption recognized as a standard threat to human rights?}

We saw earlier that the use of state power to steal, extort or embezzle citizen's property has been a recurrent concern of political theorists for thousands of years, and that Lockean-cum-republican prohibitions on having citizen's property (or 'fortune', 'estate' etc.) vulnerable to arbitrary power provided a strong moral justification for building institutions to protect against such depredations.

Why then was state corruption - at least in its most widespread and flagrant instantiations - not seen as a threat worth explicit mention in any of the Covenants or Declarations (a fact stressed by (Rose, 2016))?

The period in which the human rights instruments were drafted (in the 1940s for the Declaration and the 1950s to 1960s for the major Covenants) provides us with a possible explanation. The defining statement of human rights - the Universal Declaration of 1948 - was drafted in the wake of the Second World War. In that context, Nazi aggression, fascism and racism - culminating in the Holocaust - cast a large shadow over proceedings (Morsink, 1999). In comparison with such atrocity crimes, the assaults on human dignity and wellbeing caused by widespread and flagrant state theft must have looked rather trivial.

Or, at least, so it might have seemed to the drafters in 1946-1948, who were all representatives of the newly minted General Assembly - which, at that moment, included a significant number of colonial powers, and few representatives of colonialized peoples. Thus, while there were many countries then suffering under the yoke of state-sanctioned theft of their riches and resources, those countries did not yet have a seat at the global table. When this balance began to shift in the new world order, the emerging members sought to remedy the drafters' failure to explicitly highlight the grievances of colonized peoples (Moyn, 2010). These changes gave rise to the 'right to self-determination' enshrined as the first human right in both the major Covenants. Here too, it makes sense that the focus was not on corruption 
per se. Even if we confine our concerns to issues of state theft (and not colonialism's myriad other injustices), colonialized peoples isolated the problem plaguing them as the specific problem of foreign theft of resources and riches. It was not until well after the drafting of both the Declaration and the Covenants that networked state corruption - of an autochthonous government of its own people - reared its head as the grave threat to human freedom and dignity that it has become today ((ICoHRP) \& (TI), 2009; (OHCHR), 2013; Chayes, 2015). We might speculate therefore, that in claiming the human right to freedom from corruption in the twenty-first century, human rights would not be advancing into new territory, but rather reacquiring an earlier stronghold.

Ultimately, this fleeting lack of concern with the rapaciousness of local rulers may prove something of a historical anomaly. Certainly, to many of the early modern period, from Machiavelli through Locke, one of the most vivid threats to human flourishing - and a common cause of civil unrest - lay in predatory takings by powerful monarchs and aristocrats. ${ }^{15}$ Natural rights of the early enlightenment concerned themselves with this threat among others, and it may be that in the globalized and capitalized world of the twentieth-first century, the old threats loom large once again.

\section{Conclusion: A Deep Conceptual Link}

This paper has investigated the overlap and relations between three normative concepts: corruption, arbitrary power and arbitrary interference. Figure 1 illustrates the overlap between these concepts. The Arbitrary Power prohibited by natural rights overlaps substantially with the Arbitrary Interference proscribed by human rights. (The area of non-overlap between the two lies in cases where Lockeancum-republican rights differ in substance from the rights enumerated in the Declaration. ${ }^{16}$ ) Whenever corruption impacts directly and substantially on key freedoms and interests, then it overlaps with these rights-based prohibitions. Naturally, there are many other ways of violating human and natural rights that have nothing to do with corruption (tyranny, aggressive war, racist oppression, and so on) - thus explaining the large areas of arbitrary power and interference not encompassed by corruption. Equally, many cases of corruption will not amount to violations of human or natural rights, though we have seen that they might still facilitate or lead to such violations.

\footnotetext{
${ }^{15}$ See (Chayes, 2015). This would explain why variations on integrity measures like the separation of powers were so prominent in thinker's minds at this period. Rather than focusing on issues of distributive justice, political theorists of the time directed their energies towards designing a system to avoid rapacious theft (as well as the religious violence and authoritarianism). See (Breakey, 2014a; Vile, 1998)

${ }^{16}$ This is a contested question. Since Locke considered need-based rights as well as freedom-based rights (Waldron, 2005), his natural rights might share much in common with the Declaration's entitlements.
} 


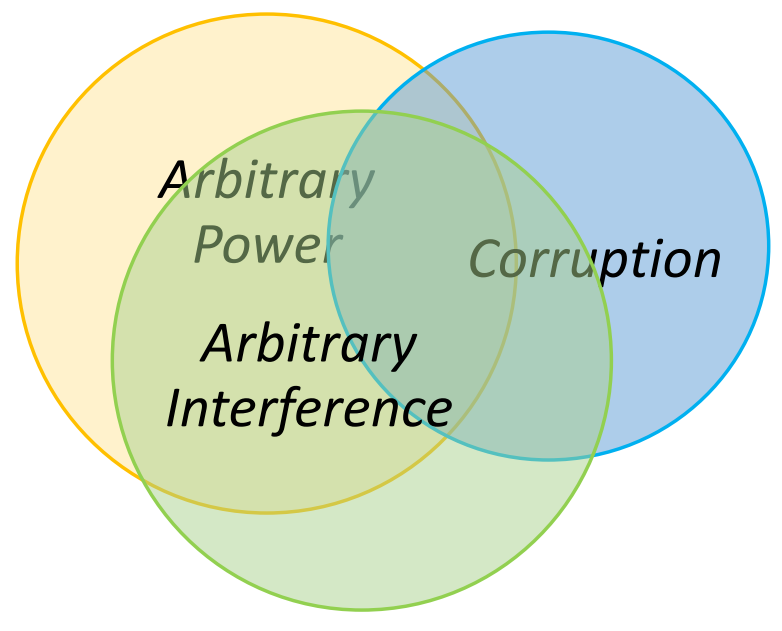

Figure 1: Overlap between Arbitrary Power, Arbitrary Interference and the Abuse of Power

The areas of non-overlap in Figure 1 imply that it is strictly incorrect to say that all people have a blanket, 'human right to freedom from (every instance of) corruption'. Some instances of corruption do not impact upon, or possess any substantial link to, the entitlements enshrined as human rights. However, the manifold links between corruption and human rights violations nevertheless vindicate victims, advocates and activists speaking the language of human rights in this context (Chayes, 2015, pp. 98-101). In particular, because of the close links between human rights and networked, horizontallyand vertically-integrated corruption, it is fair to say that such corruption constitutes a standard threat against human rights in the twenty-first century. As such, we should acknowledge and act upon the human right to freedom from systemic corruption.

This point has several practical results. It suggests there should be increased sensitivity to corruption (especially systemic corruption) in human rights thinking, institutions, courts and activism. While current investigations and reports on human rights deprecate on various instances of corruption and their impact on human rights ((HRW), 2015), the close relationship between the abuse of entrusted power and arbitrary interference in human rights implies that systemic corruption should be investigated, reported on and treated as an intrinsic violation of human rights.

These links between corruption and human rights carry implications even for countries, including many liberal democracies, where the corruption is not systemic. ${ }^{17}$ In the international context, institutions within liberal democracies can actively or unwittingly facilitate systemic corruption in other countries (Chayes, 2015, 2016). On the domestic front, we have seen that even isolated and opportunistic acts of corruption can violate particular individual's human rights. But perhaps the greater danger for liberal democracies is that isolated instances of corruption may not remain isolated for long. If there is an opportunity for ongoing illicit profit-making, corrupt agents will face a choice between (on the one

${ }^{17}$ Of course, corruption in liberal democracies can be systemic: Sampford (2009) relates the corruption system operating in Queensland, Australia prior to its effective destruction by the Fitzgerald Reforms of the 1980s and 1990s, while Chayes (2015, pp. 205-211) notes the tepid political and legal response in most developed countries to the wrongdoings of financial elites that issued in the Global Financial Crisis. 
hand) keeping their activities constrained and well-hidden, and (on the other) attempting gradual infiltration, vitiation, coercion and capture of key external institutions. If successful in these attempts, the corrupt groups will access larger revenue streams and levers of power, with less oversight and risks of punishment. This outcome will then empower their further expansion, potentially leading to systemic corruption.

In conclusion, while calls for corruption to be recognized as a violation of human rights introduce complex legal and socio-political questions (as Section II noted), a deep conceptual link lies between the natural rights concern with arbitrary power over people and property, the human rights concern with arbitrary interference with protected freedoms, and corruption's abuse of entrusted power for wrongful gain. All refer, in different language, to the proper purpose and scope of legitimate political authority, and the problems caused by usurpation of that power for private gain and political agendas.

Ultimately, the human right to freedom from systemic corruption is not a 'new' right, requiring incorporation alongside rights to liberty, education and security. Rather, this human right simply targets a new (or, at least, newly exposed) standard threat to human freedom and flourishing, namely: the arbitrary power and interference of political elites as they systematically abuse their entrusted powers to enrich themselves. Exploring the historical concern for natural rights and the republican resistance against domination helps explain why systemic corruption constitutes such an important moral concern. In prohibiting arbitrary power, respect for human rights does more than grant citizens a discrete set of protections. It provides people with a moral status that protects them against large-scale and perennial methods of human domination and subordination.

\section{References}

(HRW), H. R. W. (2015). World Report: 2015. Events of 2014. New York: Seven Stories Press.

(ICoHRP), I. C. o. H. R. P., \& (TI), T. I. (2009). Corruption and Human Rights: Making the Connection. Geneva: International Council on Human Rights Policy.

(OHCHR), O. o. t. U. N. H. C. f. H. R. (2013). The Human Rights Case Against Corruption. Retrieved from Geneva:

Beitz, C. (2009). The Idea of Human Rights. New York: Oxford University Press.

Boersma, M. (2012). Corruption: A Violation of Human Rights and Crime under International Law. Antwerp: Intersentia.

Breakey, H. (2011). Property, Persons, Boundaries: The Argument from Other-Ownership. Social Theory and Practice, 37(2), 189-210.

Breakey, H. (2012). Property. Internet Encyclopedia of Philosophy. Retrieved from http://www.iep.utm.edu/prop-con/

Breakey, H. (2014a). Dividing to conquer: Employing the separation of powers to structure institutional inter-relations. Research in Ethical Issues in Organizations, 12, 29-58.

Breakey, H. (2014b). Who's Afraid of Property Rights? Rights as Core Concepts, Coherent, Prima Facie, Situated and Specified. Law and Philosophy, 33(5), 573-603. doi:DOI 10.1007/s10982013-9190-5

Breakey, H. (2015). Positive Duties and Human Rights: Challenges, Opportunities and Conceptual Necessities. Political Studies, 63(5), 1198-1215. doi:10.1111/1467-9248.12150

Breakey, H. (2016). Compromise despite Conviction: Curbing Integrity's Moral Dangers. Journal of Value Inquiry, 50(3), 613-629. doi:DOI 10.1007/s10790-016-9541-1

Buchanan, A. (2010). Human Rights, Legitimacy and the Use of Force. New York: Oxford.

Chayes, S. (2015). Thieves of State: Why Corruption Threatens Global Security. New York: W. W. Norton \& Company. 
Chayes, S. (2016). The Structure of Corruption: A Systemic Analysis Using Eurasian Cases. Washington, DC: Carnegie Endowment for International Peace.

General-Assembly, U. N. (1948). Universal Declaration of Human Rights (UDHR). Retrieved from

General-Assembly, U. N. (1966a). International Covenant on Civil and Political Rights (ICCPR).

Retrieved from New York: http://www2.ohchr.org/english/law/pdf/ccpr.pdf

General-Assembly, U. N. (1966b). International Covenant on Economic, Social and Cultural Rights (ICESCR). Retrieved from http://www2.ohchr.org/english/law/pdf/cescr.pdf

Griffin, J. (2008). On Human Rights. Oxford: Oxford University Press.

Halldenius, L. (2003). Locke and the Non-Arbitrary. European Journal of Political Theory, 2(3), 261279.

Hassan, P. (1969). The Word "Arbitrary" As Used In The Universal Declaration Of Human Rights: "Illegal" Or "Unjust'? Harvard International Law Journal, 10(2), 225-262.

Hatchard, J. (2010). Adopting a Human Rights Approach Towards Combating Corruption. In M. Boersma \& H. Nelen (Eds.), Corruption and Human Rights: Interdisciplinary Perspectives (pp. 7-23). Antwerp: Intersentia.

Jacobs, H. M. (2013). Private property and human rights: A mismatch in the 21 st century? International Journal of Social Welfare, 22, 85-101.

Kumar, R. (2011). Corruption and human rights in India: comparative perspectives on transparency and good governance. Oxford: Oxford University Press.

Locke, J. (1690/1947). Two Treatises of Government. New York: Hafner.

Lovett, F. (2012). What counts as arbitrary power? Journal of Political Power, 5(1), 137-152.

Machiavelli, N. (1514/1961). The Prince (G. Bull, Trans.). Harmondsworth: Penguin.

McCammon, C. (2015). Domination: A Rethinking. Ethics, 125, 1028.

Mchangama, J. (2011). The Right to Property in Global Human Rights Law. CATO Policy Report, May/June.

Morsink, J. (1999). The Universal Declaration of Human Rights: Origins, Drafting and Intent. Philadelphia: University of Pennsylvania.

Moyn, S. (2010). The Last Utopia: Human Rights in History. London: Belknap Press.

Nacol, E. C. (2011). The Risks of Political Authority: Trust, Knowledge and Political Agency in Locke's Second Treatise. Political Studies, 59(3), 580-595.

Pettit, P. (1996). Freedom as Antipower. Ethics, 106(3), 576-604.

Rajagopal, B. (1999). Corruption, Legitimacy and Human Rights: The Dialectic of the Relationship. Connecticut Journal of International Law, 14, 495-507.

Raz, J. (1986). The morality of freedom. Oxford: Clarendon Press.

Rose, C. (2016). The Limitations of a Human Rights Approach to Corruption. International and Comparative Law Quarterly, 65, 405-438.

Sampford, C. (2009). From Deep North to International Governance Exemplar. Griffith Law Review, $18(3), 559-575$.

Sen, A. (1970). The Impossibility of a Paretian Liberal. Journal of Political Economy, 78, 152-157.

Sen, A. (2004). Elements of a Theory of Human Rights. Philosophy and Public Affairs, 32(4), 315-356.

Shah, S. (2014). Detention and Trial. In D. Moeckli, S. Shah, \& S. Sivakumaran (Eds.), International Human Rights Law (pp. 259-285). Oxford: Oxford University Press.

Shue, H. (1980). Basic Rights: Subsistence, Affluence and US Foreign Policy. Princeton: Princeton University Press.

Tuckness, A. (2008). John Locke and Public Administration. Administration \& Society, 40(3), 253-270.

Tully, J. (1980). A Discourse on Property: John Locke and his Adversaries. Cambridge: Cambridge University Press. 
Vile, M. J. C. (1998). Constitutionalism and the Separation of Powers (2nd Edition ed.). Indianapolis: Liberty Fund.

Waldron, J. (1993). Liberal rights. New York: Cambridge University Press.

Waldron, J. (2005). Nozick and Locke: Filling the Space of Rights. Social Philosophy and Policy, 22, $81-110$. 